\title{
Effects Of Some Compounds on The $\alpha$-amylase Activity Purified From Abena-24 Wheat Flour Treated By Tribolium confusum
}

\author{
M. K. Ismail \\ Department of Chemistry \\ College of Science, Mosul University \\ Received \\ Accepted \\ 27/3/2004 \\ $16 / 2 / 2005$
}

\section{الخلاصة}

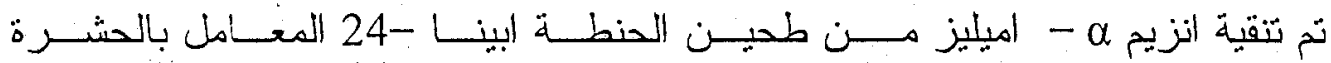

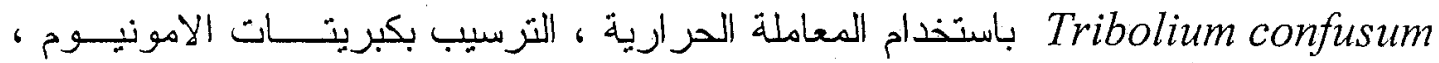

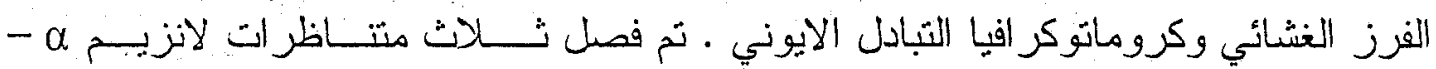

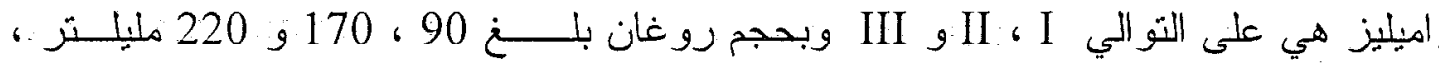

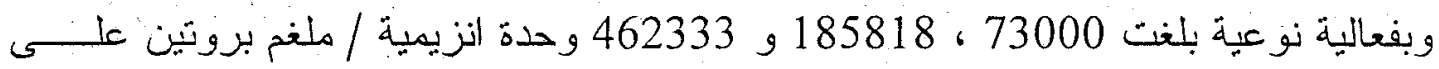
التو اللي مقارنة بالانزيم الخام.

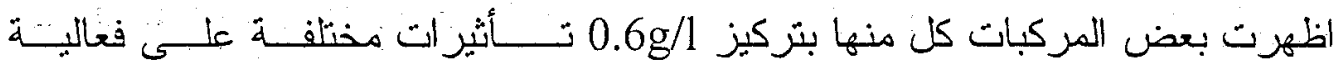

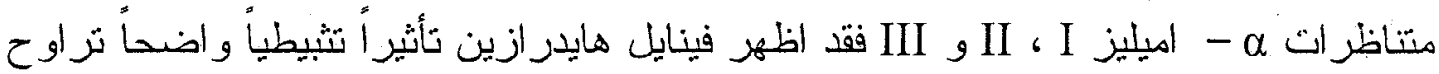

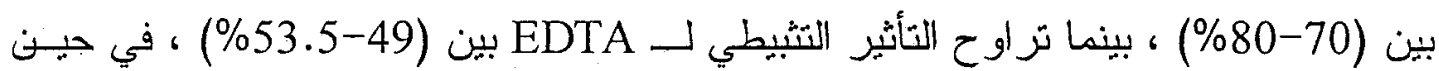

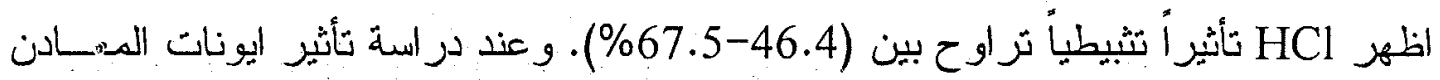

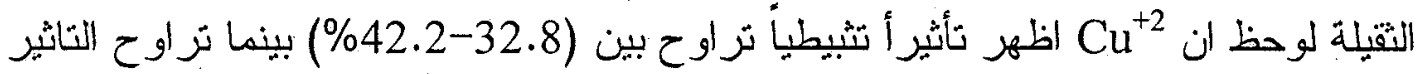

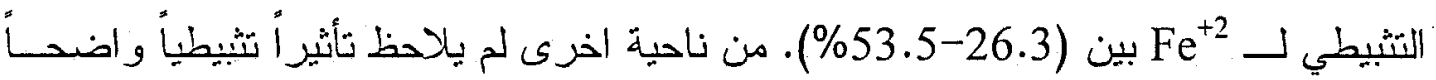

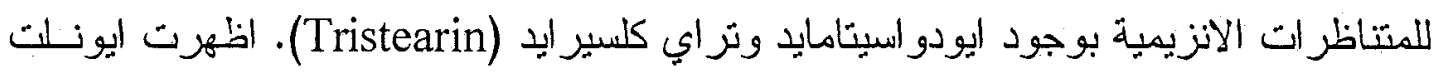

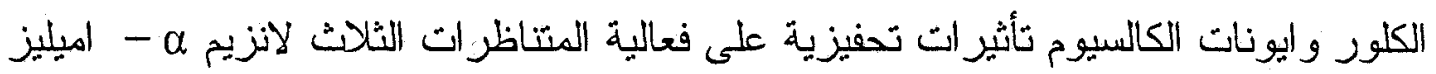
نراوحت بين (27-45.4\%) لايون الكلور وبين (15-82\%) لايون الكالسيوم.

\section{ABSTRACT}

$\alpha$-Amylase was purified from Abena-24 wheat flour treated by Tribolium confusum insect using heat treatment, ammonium sulphate precipitation, dialysis, and anion exchange chromatography.

Three $\alpha$-amylase isoenzymes were isolated (I, II and III) with elution volume of 90,170 and $220 \mathrm{ml}$ respectively, with specific activity of 73000,185818 and $462333 \mathrm{mu} / \mathrm{mg}$ protein, respectively compared 
with the crude enzyme. Many compounds showed different effects on the $\alpha$-amylase isoenzymes activity. Phenyl hydrazine, EDTA and $\mathrm{HCl}$ showed an inhibitory effect between (70-80\%), (49-53.5\%) and (46.4$67.5 \%)$ respectively. Using heavy metales, it was observed that $\mathrm{Cu}^{+2}$ caused an inhibitory effect between (32.8-42.2\%), while $\mathrm{Fe}^{+2}$ caused an inhibitory effect between (26.3-53.5\%). On the other hand, no significant inhibitory effect was shown with iodoacetamide and tristearin. Chloride ion and calcium ion showed an activitory effects on the $\alpha$-amylase isoenzymes I, II and III ranging between (27-45.4\%) for $\mathrm{Cl}^{-}$and (15-82\%) for $\mathrm{Ca}^{+2}$.

\section{INTRODUCTION}

$\alpha$-Amylase (EC3.2.1.1.) is one of the hydrolytic enzymes that hydrolyses the dietary starch and glycogen into glucose and maltose (1). Wheat $\alpha$-amylase is an important enzyme in affecting the quality of wheat (2). Wheat and wheat flour were attacked by insects, causing an increase in the $\alpha$-amylase activity and a high damage of the commercial value (3). Tribolium confusum is one of the important insects that increased $\alpha$-amylase activity (4). Many peptides and proteins are affect $\alpha$-amylase activity. Tendamistat, is a proteinaceous inhibitor of $\alpha$ amylase (5). Cyclic hexapeptides and cyclic tetrapeptides are used for inhibition $\alpha$-amylase activity (6). Because of the difficulties to obtain and using such inhibitors, therefore we study the effect of other compounds that affect $\alpha$-amylase activity.

\section{MATERIALS AND METHODS}

The adult (Tribolium confusum) had been taken from Mosul-flour factory and incubated at specific condition of $\left(27^{\circ} \mathrm{C}\right)$ and $(70 \%)$ humidity for 4 weeks. Abena-24 flour obtained from Mosul-flour factory and used as source of enzyme.

\section{Assay of $\alpha$-amylase :}

$\alpha$-amylase activity was determined using dinitro-salicylic acid method (7). The standard curve of maltose was determined by using a series of maltose concentration as standards.

The unit of $\alpha$-amylase activity is (mu), defined as the number of micromoles of $\alpha(1-4)$ glycosidic bonds hydrolyzed per minute.

\section{Protein determination:}

Protein in $\alpha$-amylase extracts and isoenzymes were estimated by modified Lowry method (8). 


\section{Extraction and purification of $\boldsymbol{\alpha}$-amylase enzyme:}

This has been done as described in (9) with some modifications. Sixty grams of affected wheat flour was stirred for two hours in $4 \mathrm{C}$, using $125 \mathrm{ml}$ of $0.05 \mathrm{M}$ calcium acetate buffer containing $0.1 \mathrm{M} \mathrm{CaCl}_{2}$. The slurry was centrifuged at $9500 \mathrm{~g}$ for $10 \mathrm{~min}$. The supernatant was heated at $60^{\circ} \mathrm{C}$ for $15 \mathrm{~min}$ at $\mathrm{pH} 6.6$ then cooled in an ice bath $\left(2-3^{\circ} \mathrm{C}\right)$. It is centrifuged at $5000 \mathrm{~g}$. The filtrate, then dialyzed over night against $0.2 \%$ calcium acetate. The dialysate fraction was loaded on diethyl amino ethyle cellulose (DEAE-cellulose) column $(2 \times 50 \mathrm{~cm})$ with $(0.05 \mathrm{M})$ calcium acetate buffer, $5 \mathrm{ml}$ fraction was collected every $5 \mathrm{~min}$.

\section{$\alpha$-Amylase effectors:}

Compounds in table (2) and table (3), each with concentration of $0.6 \mathrm{~g} / \mathrm{L}$, were used to determine their effects on $\alpha$-amylase isoenzymes activity. The isoenzymes I, II and III were preincubated with each of these compounds for $30 \mathrm{~min}$ at $37^{\circ} \mathrm{C}$ using starch as substrat then the activity was assayed using Bendelow method (7).

\section{$\alpha$-Amylase purification:}

\section{RESULTS}

The results in table (1) showed that the specific activity of crude $\alpha$ amylase in wheat flour treated with Tribolium confusum was $22177 \mathrm{mu} / \mathrm{mg}$ protein. The activity after heat treatment was $29879 \mathrm{mu} / \mathrm{mg}$ protein. Fig. (1) showed the elution profile obtained by purification of $\alpha$ amylase using DEAE-cellulose. Three peaks were obtained (I, II and III) with elution volums of (90), (170) and (220)ml respectively, and with specific activity of 73000,185818 , and $462333 \mathrm{mu} / \mathrm{mg}$ protein respectively. The purification folds were $3.3,8.4$ and 20.8 respectively compared with the crude enzyme, table (1).

\section{$\alpha$-Amylase inhibition:}

Examination of the effect of some compounds, each at a concentration of $0.6 \mathrm{~g} / \mathrm{L}$ showed that phenyl hydrazine, EDTA, and $\mathrm{HCl}$ had a significant inhibitory effects on the activity of $\alpha$-amylase isoenzymes I, II and III. Phenyl hydrazine inhibited the enzymatic activity by $70 \%, 73.3 \%$ and $79.5 \%$ respectively, table (2). EDTA inhibited the activity by $53.5 \%, 49.0 \%$ and $50.7 \%$ respectively, while $\mathrm{HCl}$ showed an inhibitory effect by $46.4 \%, 64.0 \%$ and $67.0 \%$ respectively.

Heavy metal ions showed different inhibitory effects. The ion $\mathrm{Cu}^{+2}$ inhibited the activity of $\alpha$-amylase isoenzymes I, II and III by $3.6 \%$, 
$25.4 \%$ and $37.3 \%$ respectivel, while $\mathrm{Fe}^{+2}$ showed an inhibitory effect by $53.5,26.3 \%$ and $48.5 \%$ respectively.

Iodoacetamide inhibited the activity of I and II isoenzymes by $9.0 \%$ and $15 \%$ but had no effect on the III isoenzyme activity, while tristearin showed an inhibitory effect of $3.6 \%, 15 \%$ and $7.3 \%$ to each of I, II and III isoenzymes, table (2).

\section{$\alpha$-Amylase activation:}

Table (3) showed that $\mathrm{Cl}^{-}$ion activated the $\alpha$-amylase isoenzymes I, II, and III by $45.4 \%, 38.0 \%$ and $27.4 \%$ respectively. $\mathrm{Ca}^{+2}$ ion activated I, II, and III isoenzymes by $58.8 \%, 82.3 \%$, and $15 \%$ respectively, table (3).

\section{DISCUSSION}

$\alpha$-Amylase isolated from wheat flour had a high activity (10). Tribolium confusum increased wheat flour $\alpha$-amylase activity (4). The properties of $\alpha$-amylase enzyme in abena-24 wheat flour was studied (11). In this study the effects of some compounds were studied. Phenyl hydrazine showed a significant inhibitory effect on the isoenzymes activity, indicating that carbonyl group were necessary to maintain the catalytic reactivity of the isoenzymes(12). A metal chelator EDTA, also showed a significant inhibitory effect, this indicated that the cations such as $\mathrm{Cu}^{+2}$ and $\mathrm{Mg}^{+2}$ if present does participate in the isoenzymes activity (13). $\mathrm{HCl}$ treatment caused a significantly reduction in the isoenzymes activity because of the modification of the substrate by the acid treatment and not with a failure to inactivate $\alpha$-amylase activity (14). The heavy metal ions $\mathrm{Cu}^{+2}$ and $\mathrm{Fe}^{+2}$ had a different inhibitory effects on the isoenzymes activity table $(2)$. This was attributed to the heavy metal binding effects (15). The results were similar to those in immature hard red spring wheat $\alpha$-amylase (16). On the other hand, iodoacetamide caused a slight inhibition on the isoenzymes activity, indicating that free sulfhydryl groups if present, it does not participate in the activity of the isoenzymes (15). This was similar to that of the immature hard red spring wheat $\alpha$-amylase (16). Tristearin also had slightly inhibitory effect on the isoenzymes activity. The activity of $\alpha$-amylase isoenzymes was increased with calcium and chloride ions table (3). It was reported that $\alpha$ amylase was a metaloenzyme and its activity increase with $\mathrm{Ca}^{+2}$ and $\mathrm{Cl}^{-}$ (17). 
Table (1): Partial purification of abena-24 $\alpha$-amylase treated with insect

\begin{tabular}{|l|l|l|l|l|l|l|}
\hline purification steps & $\begin{array}{l}\text { total } \\
\text { volume } \\
(\mathbf{m l})\end{array}$ & $\begin{array}{l}\text { enzyme } \\
\text { activity } \\
(\mathbf{m u} / \mathbf{m l})\end{array}$ & $\begin{array}{l}\text { protein } \\
(\mathbf{m g} / \mathbf{m l})\end{array}$ & $\begin{array}{l}\text { specific } \\
\text { activity } \\
(\mathbf{m u} / \mathbf{m g})\end{array}$ & $\begin{array}{l}\text { purification } \\
\text { fold }\end{array}$ & $\begin{array}{l}\text { recovery } \\
\mathbf{( \% )}\end{array}$ \\
\hline Crude extract & 13.5 & 17520 & 0.79 & 22177 & 1.0 & 100 \\
\hline Heat treatment & 11 & 12848 & 0.43 & 29879 & 1.4 & 73.3 \\
\hline$\left(\mathbf{N H}_{4}\right)_{2} \mathbf{S O}_{4}$ ppt & 16 & 14016 & 0.18 & 77867 & 3.5 & 80.0 \\
\hline Dialysis & 14 & 7592 & 0.15 & 50613 & 2.3 & 43.3 \\
\hline $\begin{array}{l}\text { Ion-exchange } \\
\text { Chromatograghy }\end{array}$ & & & & & & \\
\hline Peak I & 60 & 2920 & 0.040 & 73000 & 3.3 & 16.6 \\
\hline Peak II & 20 & 4088 & 0.022 & 185181 & 8.4 & 23.3 \\
\hline Peak III & 30 & 5548 & 0.012 & 462333 & 20.8 & 31.6 \\
\hline
\end{tabular}

Table (2): Inhibition Effect of some compounds on the activity of abena-24 $\alpha$ amylase isoenzymes treated with insect.

\begin{tabular}{|c|c|c|c|c|c|c|}
\hline \multirow[b]{2}{*}{ Inhibitor $0.6 \mathrm{~g} / \mathrm{L}$} & \multicolumn{2}{|l|}{ Peak I } & \multicolumn{2}{|l|}{ Peak II } & \multicolumn{2}{|l|}{ Peak III } \\
\hline & $\begin{array}{l}\text { Activity } \\
\mathrm{mu} / \mathrm{ml}\end{array}$ & $\begin{array}{l}\text { Inhibitory } \\
\text { effect }(\%)\end{array}$ & $\begin{array}{l}\text { Activity } \\
\mathrm{mu} / \mathrm{ml}\end{array}$ & $\begin{array}{l}\text { Inhibitory } \\
\text { effect }(\%)\end{array}$ & $\begin{array}{l}\text { Activity } \\
\mathrm{mu} / \mathrm{ml}\end{array}$ & $\begin{array}{l}\text { Inhibitory } \\
\text { effect }(\%)\end{array}$ \\
\hline$\ldots \ldots \ldots$ & 3247 & & 3934 & $\ldots \ldots$ & 4815 & $\ldots \ldots$ \\
\hline Phenylhydrazine & 974 & 70.0 & 1047 & 73.3 & 9817 & 79.5 \\
\hline EDTA & 1509 & 53.5 & 2003 & 49.0 & 2373 & 50.7 \\
\hline Hel & 1739 & 46.4 & 1415 & 64.0 & 1565 & 67.5 \\
\hline $\mathrm{CuSO}_{4}$ & 2180 & 32.8 & 2665 & 32.2 & 2780 & 42.2 \\
\hline $\mathrm{FeSO}_{4}$ & 1509 & 53.5 & 2898 & 26.3 & 2480 & 48.5 \\
\hline Iodoacetamide & 2955 & 9.0 & 3340 & 15.0 & 4815 & Zero \\
\hline Tristearin & 3130 & 3.6 & 3340 & 15.0 & 4451 & 7.5 \\
\hline
\end{tabular}

Table (3): Activation effect of some ions on the activity of abena-24 $\alpha$ amylase isoenzymes treated with insect.

\begin{tabular}{|c|c|c|c|c|c|c|}
\hline \multirow[b]{2}{*}{$\begin{array}{l}\text { Activator } \\
0.6 \mathrm{~g} / \mathrm{L}\end{array}$} & \multicolumn{2}{|l|}{ Peak I } & \multicolumn{2}{|l|}{ Peak II } & \multicolumn{2}{|l|}{ Peak III } \\
\hline & $\begin{array}{l}\text { Activity } \\
\mathrm{mu} / \mathrm{ml}\end{array}$ & $\begin{array}{l}\text { Activatory } \\
\text { effect }(\%)\end{array}$ & $\begin{array}{l}\text { Activity } \\
\mathrm{mu} / \mathrm{ml}\end{array}$ & $\begin{array}{l}\text { Activatory } \\
\text { effect }(\%)\end{array}$ & $\begin{array}{l}\text { Activity } \\
\text { mu/ml }\end{array}$ & $\begin{array}{l}\text { Activatory } \\
\text { effect }(\%)\end{array}$ \\
\hline$\ldots \ldots$ & 3247 & $\ldots \ldots$ & 3034 & $\ldots \ldots$ & 4015 & $\ldots \ldots$ \\
\hline $\mathrm{Cl}^{-}$ & 4722 & 45.4 & 4189 & 38.0 & 5116 & 27.4 \\
\hline $\mathrm{Ca}^{+2}$ & 5159 & $58: 8$ & 51534 & 82.3 & 4618 & 15.0 \\
\hline
\end{tabular}


Activity $\times 10$

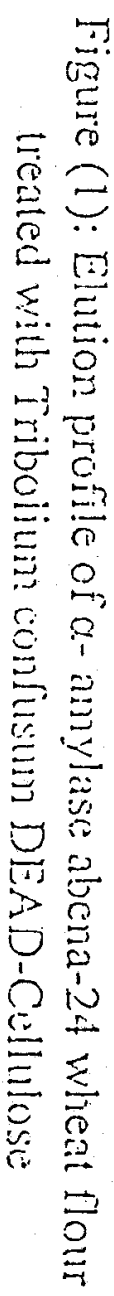

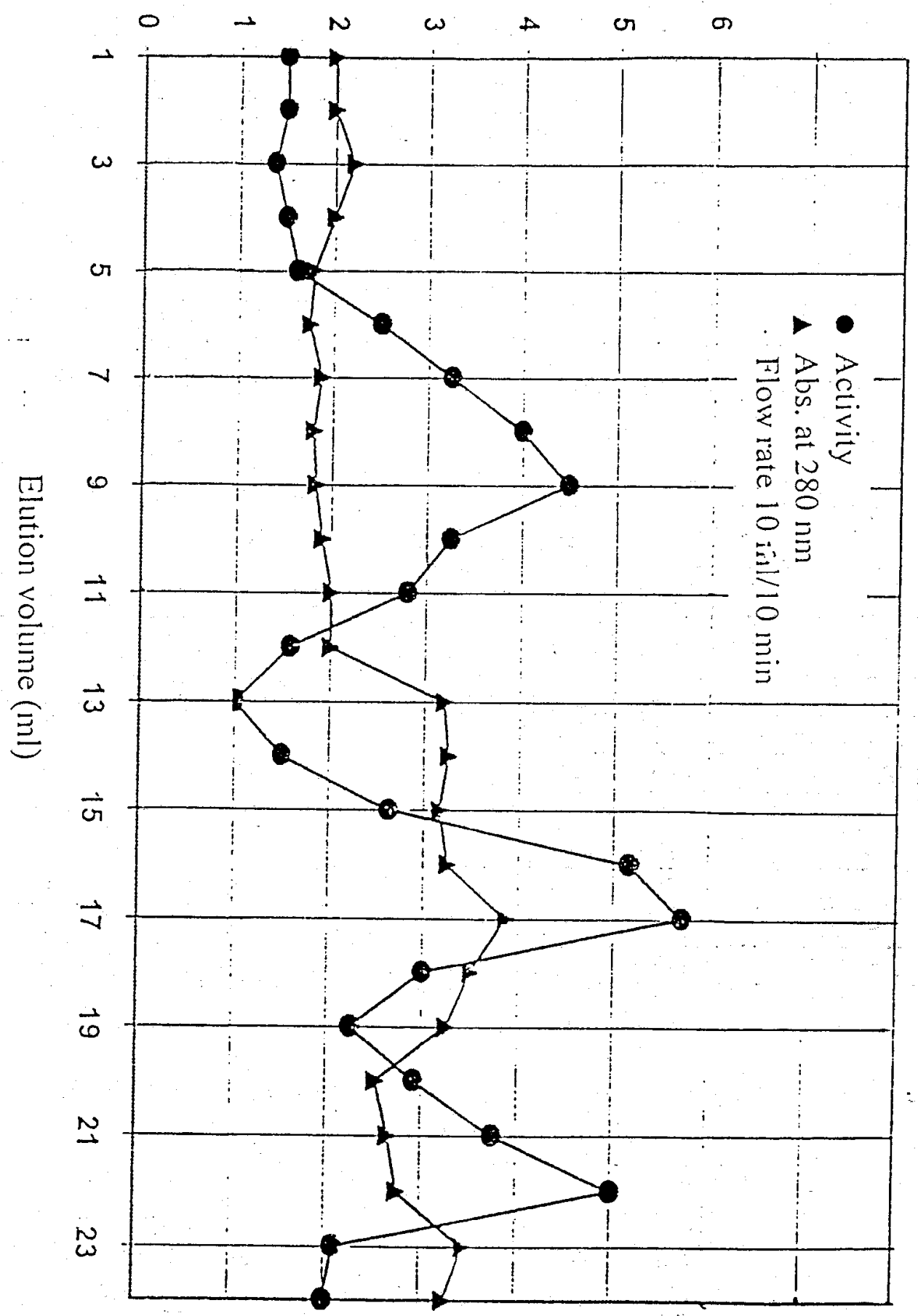




\section{REFERENCES}

1.Kaplan L.A. and pesce A.J., Clinical chemistry, U.S.A., Mosby, 11011105 (1984).

2.Appleman A.A. Biochemical Microbiological. New York. N.Y. Consultants Bureau, 26(5):488 (1991).

3.Jamil M.A.A., M. Sc. Thesis, College of Science, University of Salahaddin (1990).

4.Jamil L.A., Alkatib S.M. and Ismail M.K., Raf. J. Sci. 5(3): 165-173.

5.Etzkom R.A., Guo T.Y., and Tao B.O., J. Am. Chem. Soc., 116:1041410425 (1994).

6.Matter A.J, Hans H.L., Kessler R.M., and Horst S.S., J. Am. Chem. Soc., 117:3347-3359 (1995).

7.Bendelow VM., J. Inst. Brew., 69:467-470 (1963).

8.Schartrle GR. and Pollack RL., Anal. Biochem., 51:654-655 (1973).

9.Bilmanov Mk. , Furro DV. and Frantser AB., Nauka, Alma-Ata., 92 (1974).

10.Jamil L.A. , Aammody N.S. and Ismail M.K., J. Edu. Sci. 23:54-62 (1998).

11.Jamil L.A. , Aammody N.S. and Ismail M.K., J. Edu. Sci., 51:62-72 (2001).

13.Stephen HF. , Keith LM. , Heorge IHH. and Frank, RNG., Biochemistry, 19:3039-3047 (1980).

14.Fuller A.M., J. Sci. Fd. Agric., 21:26-30 (1970).

15.Murray RK. , Ganner DK. , Mayes PA., Harpers. Biochemistry. 24th ed.

California, Apploton and Lange, 82-88 (1996).

16.Marchylo B. , Kruger JE. and Irvine GN., Gereal chemistry, 53(2):157173 (1978).

17.Hsiu J. , Fischer EH. and Stein, EA., Biochem., 3:61-66 (1964). 